\title{
Efektivitas Pendekatan Open Ended Dalam Pembelajaran Matematika
}

\author{
Syahrudi
}

SMA Islam Terpadu Granada

\begin{abstract}
This is a quasi-experimental quantitative study to find the effectiveness of the open-ended approach in mathematics learning in terms of the learning outcomes of students. The population were all students in class X of SMA Islam Terpadu Granada Samarinda in the even semester, while sampling was done by cluster sampling or group samples based on average test scores. There were two sample classes, namely class $X$ Ikhwan as the experimental class with 30 students and class X Akhwat as the control class with 30 students. The instrument was a written essay test consisted of 5 items. Research data collection consisted of two stages, namely the first stage of data collection through pre-test given to the experimental class and the control class. The second stage was taking post-test data given to the experimental class and control class after being given learning. The data analysis using the $t$-test, while the normality test and homogeneity test were conducted. Furthermore, we had statistic thit $=2.818$ and from table we had $t_{t a b}=1.992$. Because thit $>t_{t a b}$, which was obtained $2.818>1.992$, then $H_{0}$ was rejected or $H_{1}$ was accepted.
\end{abstract}

Keywords: effectiveness, learning, open ended

\section{Pendahuluan}

Pendidikan adalah salah satu bentuk perwujudan kebudayaan manusia yang dinamis dan sarat perkembangan. Oleh karena itu, perubahan atau perkembangan pendidikan adalah hal yang memang seharusnya terjadi sejalan dengan perubahan budaya kehidupan. Perubahan dalam arti perbaikan pendidikan pada semua tingkat perlu terus-menerus dilakukan sebagai antisipasi kepentingan masa depan. Tanpa pendidikan manusia tidak akan berkembang dan bahkan akan terbelakang. Pendidikan akan merangsang kreativitas seseorang agar sanggup menghadapi tantangantantangan alam, masyarakat, teknologi serta kehidupan yang semakin kompleks.

Namun salah satu masalah yang dihadapi dunia pendidikan kita adalah masih lemahnya proses pembelajaran. Dalam proses pembelajaran, siswa kurang didorong untuk mengembang-kan kemampuan berpikir. Proses pembelajaran di dalam kelas diarahkan kepada kemampuan siswa untuk menghafal informasi, siswa dipaksa untuk mengingat dan menimbun berbagai informasi tanpa dituntut untuk memahami informasi yang diingatnya itu untuk menghu-bungkannya dengan kehidupan sehari-hari. Karena pembelajaran adalah kegiatan yang bertujuan untuk membelajarkan siswa. Proses pembelajaran itu merupakan rangkaian kegiatan yang melibatkan berbagai komponen. Oleh karena itu, setiap guru harus memahami sistem pembelajaran yang efektif yang dapat membantu siswa. Keefektivan pem-belajaran adalah hasil guna yang diperoleh setelah pelaksanaan proses belajar mengajar. Efisiensi dan keefektivan mengajar dalam proses interaksi belajar yang baik adalah segala daya upaya guru untuk membantu para siswa agar bisa belajar dengan baik. Untuk 
mengetahui keefektivan mengajar dengan mem-berikan tes, sebab hasil tes dapat dipakai untuk mengevaluasi berbagai aspek proses pengajaran.

Suatu pembelajaran dikatakan efektif apabila memenuhi persyaratan umum keefektivan pengajaran, yaitu:

a. Presentasi waktu belajar siswa yang tinggi dicurahkan terhadap KBM.

b. Rata-rata perilaku melaksanaan tugas yang tinggi di antara siswa.

c. Ketetapan antara kandungan materi ajaran dengan kemampuan siswa (orientasi keberhasilan belajar) diutamakan.

d. Mengembangkan suasana belajar yang akrab dan positif (Trianto, 2009:20).

Matematika merupakan salah satu ilmu pengetahuan yang dapat menjadikan manusia untuk berfikir logis, teoritis, rasional, dan percaya diri. Dalam upaya meningkatkan kemampuan matematika seperti yang diharapkan, guru perlu mempersiapkan dan mengatur strategi penyampaian materi matematika kepada siswa. Hal ini dilakukan selain untuk mempersiapkan pedoman bagi guru dalam penyampaian materi, juga agar setiap langkah kegiatan pencapaian kompetensi untuk siswa dapat dilakukan secara bertahap, sehingga diperoleh hasil pembelajaran matema-tika yang optimal, disamping itu dalam belajar matematika pada dasarnya seseorang tidak terlepas dari masalah karena berhasil atau tidaknya seseorang dalam matematika ditandai adanya kemampuan dalam menyele-saikan masalah yang dihadapinya. Oleh karena itu, guru harus dapat menciptakan suasana pembelajaran yang efektif pada saat pelajaran matematika.

Untuk melaksanakan pembelajaran matematika seperti tersebut, diperlukan beberapa kecakapan guru untuk memilihkan suatu model pembelajaran yang tepat, baik untuk materi ataupun situasi dan kondisi pembelajaran saat itu. Sehingga pembelajaran tersebut dapat merangsang siswa untuk memperoleh kompetensi yang diharapkan. Dengan demikian siswa mampu menyelesaikan berbagai permasalahan baik dalam pelajaran ataupun dalam kehidupan sehari-hari.

Salah satu alternatif model pembelajaran yang dapat memenuhi prinsip pembelajaran matematika tersebut yaitu dengan pendekatan open-ended. Pendekatan ini menyajikan suatu permasalahan yang memiliki metode penyelesaian yang benar lebih dari satu, pada prinsipnya pendekatan open-ended sama dengan pembelajaran berbasis masalah yaitu suatu pendekatan pembelajaran yang dalam prosesnya dimulai dengan memberi suatu masalah kepada siswa. Pendekatan open-ended dapat membe-ri kesempatan kepada siswa untuk memperoleh pengetahuan atau pengalaman menemukan, mengenali, dan memecahkan masalah dengan beberapa teknik. Namun, pada pendekatan open-ended masalah yang diberikan adalah masalah yang bersifat terbuka (open-ended problem) atau masalah tidak lengkap (incomplete problem). Sedangkan dasar keterbukaan masalah diklasifikasikan dalam tiga tipe, yakni:

1) Prosesnya terbuka, maksudnya masalah itu memiliki banyak cara penyelesaian yang benar.

2) Hasil akhirnya terbuka, maksudnya masalah itu memiliki banyak jawaban yang benar.

3) Cara pengembangan lanjutannya terbuka, maksudnya ketika siswa telah menyelesaikan masalahnya, mereka dapat mengembangkan masalah baru yaitu dengan cara merubah kondisi masalah sebelumnya (asli). 
Berdasarkan hasil observasi dan pengamatan peneliti nilai rata-rata hasil ulangan semester matematika di SMA Islam Terpadu Granada Samarinda masih rendah, karena keseluruhan rata-ratanya kurang dari KKM (Kriteria Ketuntasan Minimal).

Di samping nilai rata-rata yang masih rendah, cara mengajar guru di kelas menggunakan pembelajaran secara konvensional. Dimana guru masih mendominasi pembelajaran sementara siswa pasif. Paradigma lama masih melekat karena kebiasaan yang belum berubah, paradigma mengajar masih tetap dipertahankan dan belum berubah menjadi peradigma membelajarkan siswa, sehingga dengan menggunakan pendekatan open ended dapat membuat proses pembelajaran yang berpusat pada siswa.

\section{Metodologi Penelitian}

Jenis penelitian yang digunakan adalah penelitian eksperimen semu (quasi experimental). Mengukur hasil belajar siswa adalah dengan menggunakan tes. Rancangan eksperimen yang digunakan adalah Randomized Control Group PretestPosttest Design. Adapun rancangan Randomized Control Group PretestPostest Design terlihat pada tabel 3.1 sebagai berikut:

Tabel 1 Rancangan Penelitian (Control Group Pretest-Posttest)

\begin{tabular}{cccc}
\hline Group & Pretest & $\begin{array}{c}\text { Perlaku- } \\
\text { an }\end{array}$ & Postest \\
\hline $\begin{array}{c}\text { Group } \\
\text { Eksperimen }\end{array}$ & $\mathrm{T}_{1}$ & $\mathrm{X}$ & $\mathrm{T}_{2}$ \\
\hline $\begin{array}{c}\text { Group } \\
\text { Kontrol }\end{array}$ & $\mathrm{T}_{1}$ & - & $\mathrm{T}_{2}$ \\
\hline
\end{tabular}

(Suryabrata, 2006:105)
$\mathrm{T}_{1}=$ Tes hasil belajar sebelum diterapkannya metode pembelajaran (Pretest).

$\mathrm{T}_{2}=$ Tes hasil belajar setelah diterapkannya metode pembelajaran (Postest).

$\mathrm{X}=$ Perlakuan dengan menggunakan pendekatan open ended.

Sebelum menerapkan pembelajaran pada kelas eksperimen dan kelas kontrol terlebih dahulu diadakan pretest, dari skor pretest yang diperoleh dilakukan uji normalitas, uji kesamaan dua varians (homogenitas), dan uji kesamaan rata-rata untuk mengetahui kondisi awal sampel. Kemudian pada kelas eksperimen diterapkan pembelajaran matematika dengan pendekatan open ended. Sedangkan pada kelas kontrol diterapkan pembelajaran konvensional. Setelah proses belajar mengajar selesai, dilakukan posttest untuk mengetahui hasil belajar siswa dalam pembelajaran matematika. Posttest dilakukan pada kedua kelas sampel dengan soal evaluasi yang sama.

Dari skor pretest dan posttest kedua kelas sampel, dihitung skor pencapaian, yaitu skor posttest dikurangi skor pretest. Pada masingmasing kelas setelah didapat skor pencapaian, kemudian untuk uji kesamaan rata-rata diambil dari skor pencapaian masing-masing kelas, yaitu skor pencapaian pada kelas eksperimen dan skor pencapaian pada kelas kontrol. Serta dilakukan uji normalitas, uji kesamaan dua varians (homogenitas), dan uji kesamaan rata-rata atau uji pihak kanan pada skor pencapaian untuk mengetahui apakah perbedaan ratarata skor pencapaian pada kedua kelompok tersebut signifikan ataukah tidak secara statistik.

Keterangan: 


\section{Hasil Penelitian}

Analisis data menggunakan statistik inferensial data selisih nilai rata-rata posttest dan pretest menggunakan program SPSS. Adapun analisisnya sebagai berikut:

\section{a) Normalitas data}

Untuk menguji normalitas dari data kedua kelompok adalah dengan menggunakan uji kolomogorof smirnov, bahwa nilai probabilitas atau signifikan untuk pendekatan open ended adalah 0.598 dan untuk konvensional adalah 0.280. Taraf signifikasi yang digunakan adalah $\mathrm{a}=$ 0,05 . Kriteria yang digunakan yaitu terima $\mathrm{H}_{0}$ apabila nilai signifikan lebih dari tingkatan alpha yang telah ditentukan. Karena nilai signifikan untuk pendekatan open ended dan Konvensional lebih dari 0,05 maka $\mathrm{H}_{0}$ diterima, artinya data kedua kelompok berdistribusi normal.

\section{b) Homogenitas Data}

Uji Homogenitas digunakan untuk mengetahui apakah data berasal dari populasi dengan variansi yang homogen. Hipotesis sebagai berikut: $\mathrm{H}_{0}: \sigma_{1}^{2}=\sigma_{2}^{2}$

$\mathrm{H}_{1}: \sigma_{i}^{2} \neq \sigma_{j}^{2}$, untuk minimal satu pasang $(\mathrm{i}, \mathrm{j})$

Taraf signifikasi yang digunakan adalah $\mathrm{a}=0,05$. Berdasarkan lampiran 14 didapat bahwa nilai signifikan adalah 0,531 . Karena nilai signifikan lebih dari 0,05 maka $\mathrm{H}_{0}$ diterima. Ini berarti kedua data berasal dari populasi dengan variansi yang homogen.

\section{c) Uji Perbedaan Rata-rata}

Diketahui bahwa data selisih nilai tes pretest dan postest hasil belajar berdistribusi normal dengan variansi yang homogen. Uji perbedaan ratarata (pihak kanan) ini menggunakan
Uji $t$, dengan rumusan hipotesis sebagai berikut ini:

HO: $\mu_{1}=\mu_{2}$

$\mathrm{H} 1: \mu_{1}>\mu_{2}$

Tabel 2 Uji Perbedaan Rata-rata

\begin{tabular}{ccc}
\hline No & Statistik & Niai \\
\hline 1 & Uji F & 2.286 \\
\hline 2 & Uji t & 2.818 \\
\hline 3 & Signifikan & 0.006 \\
\hline 4 & Rata-rata & 4.949
\end{tabular}

(Sumber: Hasil Penelitian, 2010)

Dari hasil perhitungan dengan menggunakan SPSS yang terdapat pada tabel 2. Nilai uji perbedaan ratarata dengan menggunakan uji $t$ adalah 2,818, sehingga nilai t hitung $>\mathrm{t}$ tabel yaitu: $2,818>1,992$ maka Ho ditolak. Signifikansi yang diperoleh adalah 0,006. Dimana nilai dari signifikansi yang diperoleh dibandingkan dengan nilai apha, sehingga berdasarkan rumusan hipotesis diperoleh signifikansi < alpha yaitu: 0,006 < 0,05 maka Ho ditolak, artinya bahwa rata-rata nilai kelas eksperimen lebih baik dibandingkan nilai rata-rata kelas kontrol. Dapat disimpulkan bahwa hasil belajar siswa dengan menggunakan pendekatan open ended lebih efektif dibandingkan hasil belajar siswa dengan menggunakan pembelajaran konvensional.

\section{Simpulan dan Saran}

Berdasarkan hasil analisa data dan pembahasan maka dapat disimpulkan bahwa hasil belajar siswa dengan pendekatan open ended adalah lebih baik dibandingkan hasil belajar siswa dengan pembelajaran konvensional. Ini berarti bahwa Pendekatan open ended adalah efektif.

Dengan mengacu pada hasil penelitian yang telah dilaksanakan disarankan bagi siswa, dengan menerapkan serta menggunakan 
pendekatan open ended dapat meningkatkan hasil belajar menjadi lebih baik, serta dapat meningkatkan keaktifan, mengem-bangkan ide-ide kreatif dan pola pikir matematis dalam pembelajaran matematika.

Bagi guru, dalam pelaksanaan pendekatan open ended permasalahan sebaiknya disesuaikan dengan kemampuan peserta didik, serta dalam melaksanakan proses belajar mengajar guru perlu memilih metode yang tepat misalnya pendekatan open ended dalam materi dimensi tiga sebagai alternatif untuk meningkatkan hasil belajar siswa.

Bagi sekolah, secara tidak langsung dapat meningkatkan hasil belajar matematika siswa, maka disarankan pihak sekolah dapat menentukan kebijakan-kebijakan yang dapat menunjang peningkatan dan perkembangan pengajaran matematika tersebut

\section{Daftar Pustaka}

Sugiyono. 2009. Statistika untuk Penelitian. Bandung: Alfabeta.

Suryabrata, Sumadi. 2006. Metodologi Penelitian. Jakarta: PT Raja Grafindo Persada.

Suyatno. 2009. Menjelajah Pembelajaran Inovatif. Sidoarjo: Masmedia Buana Pustaka.

Syaban, Mumun. 2010. Menggunakan Pendekatan Open Ended untuk Memotivasi Berpikir Matematika. (Online), (http://educare.e-fkipunla.net, diakses 20 April 2019)

Syafruddin. 2008. Pendekatan Open-Ended Problem dalam Matematika.(Online), (http://spesialistorch.com/index2.php?option=comcontent\&dopdf=1\&id=1 0 diakses 22 April 2019).

Trianto. 2009. Mendesain Model Pembelajaran Inovatif Progresif. Jakarta: Kencana Prenada Media Group.

Vendiagrys, Lia. 2007. Keefektivan Pembelajaran Matematika Berbasis Problem Open Ended Terhadap Kemampuan Pemecahan Masalah Peserta Didik Kelas VII Semester II Di SMP Kecamatan Semarang Timur. (Online), (http://smacepiring.wordpress.com, diakses 20 Maret 2019)

Winkel, W. S. 1991. Psikologi Pengajaran. Jakarta: Penerbit PT grasindo

Wayan, Sukra. 2009. Pembelajaran Konvensional (Online), (http://edukasi.kompasiana.com/2009/12/20/pendekatan-pembelajarankonvensional/, diakses 15 April 2019)

Wicaksono, Agung. 2009. Efektivitas Pembelajaran. (Online),( http://tips-belajarinternet.blogspot.com/2009/08/efektivitas-pembelajaran-matematika.html diakses 15 April 2019) 